\section{Justismord og rettsmedisinernes ansvarsfraskrivelse}

I Tidsskriftet nr. 24/2008 hevder de tre rettsmedisinerne O.A. Haugen, L. UhlinHansen og I. Morild at jeg driver et «korstog mot en konstruert virkelighet» siden jeg har fremholdt at rettsmedisinere må ta sin del av ansvaret for at det er skjedd altfor mange justismord i Norge (1).

Det er imidlertid et faktum at rettsmedisinere har medvirket til atskillige justismord ved at de har avgitt erklæringer til retten som i ettertid har vist seg ikke å være holdbare. En utbredt systemfeil er at rettsmedisinere altfor ofte har sluttet fra likhet mellom funn til at det er årsakssammenheng mellom dem. Tallrike eksempler på denne systemfeilen og andre feil som rettsmedisinere har begått $\mathrm{i}$ justismordsaker er dokumentert også for norske forhold $(2,3)$.

Det er dels de samme rettsmedisinere som opptrer i retten og som (i andre saker) er medlemmer av Den rettsmedisinske kommisjon. Systemfeilene blir bl.a. av den grunn ofte ikke avdekket av kommisjonen. I stedet blir de sementert. Da Den rettsmedisinske kommisjon vurderte tannbittbeviset i 2001, det som ble ansett som et $100 \%$ sikkert bevis for at Torgersen var skyldig i det seksualdrapet han ble dømt for i 1958, uttalte de for eksempel: «Det bør utvises forsiktighet, og Domstolen bør ikke tillegge bittmerket stor bevisbyrde.» Konklusjonen er det rene sludder, fordi det ikke er mulig å trekke noen slutning fra det vi vet om likheter mellom Torgersens tenner og bittmerket til sannsynligheten for at Torgersen kan være biteren. Professor i rettsodontologi Tore Solheim har skriftlig og muntlig hevdet at tannbittbeviset i Torgersen-saken er like sikkert som et DNA-bevis. Hvorfor protesterer ikke rettsmedisinere på slik «sakkyndig» vranglære - i en drapssak? Nå er det offentlig kjent. Jeg er spent på om noen reagerer.

At det skjer forskning innenfor rettsmedisin ved våre fire medisinske fakulteter, slik Haugen og medarbeidere fremholder, har ikke forhindret rettsmedisinernes systemfeil. Jeg tror systemfeilene ville ha blitt avdekket for lenge siden dersom rettsmedisinernes erklæringer i straffesaker hadde måttet gjennomgå de samme kvalitetsvurderinger som andre medisinere underkaster seg når de leverer artikler til vitenskapelige tidsskrifter. Når rettsmedisinerne opptrer i retten, blir de i realiteten ofte kontrollert av seg selv. Jeg er enig med Haugen og medarbeidere $i$ at «juristene må skjerpe seg» (...) «slik at alvorlige feil og mangler kan bli oppdaget i tide». Men rettsmedisinerne kan ikke skylde på juristene for at feilene begås. Det er og blir rettsmedisinernes eget ansvar.

\section{Ståle Eskeland}

Universitetet i Oslo
Litteratur
1. Haugen OA, Uhlin-Hansen L, Morild I. Juristenes
korstog mot en konstruert virkelighet. Leserbrev.
Tidsskr Nor Legeforen 2008; 128: 2846-7.
2. Brandtzæg P. Eskeland S, red. Rettsmedisinsk
sakkyndighet i fortid, nåtid og fremtid. Oslo: Cap-
pelen Akademisk, 2007.
3. Bratholm A, Eskeland S, red. Justismord og retts-
sikkerhet. Oslo: Universitetsforlaget, 2008.

\section{Diskriminering av eldre leger}

Vi er mange som kan skrive under på Steinar Hagens påstand i Tidsskriftet nr. 4/2009 om at samfunnet håner eldre leger (1). Eldre lægers forening har i flere år arbeidet med å få fjernet «diskrimineringsparagrafen», og dette var også oppe til behandling på årsmøtet siste høst.

Etter et langt legeliv er det ydmykende å bli fratatt autorisasjonen utelukkende pga. alderen, uten at man har foretatt seg noe yrkesmessig eller etisk galt. De eldre legene representerer livslang erfaring og kan gjennom sine kunnskaper med enkle midler veilede og forskrive legemidler til familie og venner og dermed avlaste et svært stresset helsevesen. De kan i tillegg gi råd om når og hvor videre undersøkelse er påkrevd. Forskrivning av A-preparater bør selvsagt kreve dokumentert praksis.

Jeg har drevet solopraksis i en og samme kommune siden januar 1963 og har i tillegg vært tilsynslege ved kommunens sykehjem i 25 år. Jeg har deltatt i den kommunale vakttjenesten i 33 år. Etter endt vaktplikt i 1994 ble min praksis flyttet til sokkeletasjen i min private bolig, med $100 \mathrm{~m}^{2}$ til rådighet innredet for formålet. Fastlegeordningen ble innført i 2001, og jeg fortsatte min praksis som før. Etter fylte 70 år fikk jeg gjennom tre påfølgende søknader innvilget fortsatt fastlegefunksjon for mine gamle pasienter inntil min fastlegerettighet ble fratatt meg da jeg var 72 år gammel. Pasientene ble uten videre overført til andre lister. De fikk et rundskriv fra kommunen og NAV om at «din fastlege har sluttet», hvilket åpenbart var usant. (Den utenlandske legen som overtok brorparten av mine pasienter, reiste etter halvannet år.)

Jeg er frisk og arbeidsfør og driver min praksis en fast ukedag for ca. 150 pasienter. Basisgodtgjørelsen tilfaller andre leger i kommunen som står som «fastlege» for pasientene mine. Jeg driver for trygdens regning i henhold til «normaltariffen». Jeg har tatt forholdet opp med Legeforeningen - uten å få noen form for hjelp. De godtar med andre ord diskriminering av medlemmer som har vært trofaste mot foreningen og gjort sin jobb i 45 år.

Hvorfor fortsetter jeg min beskjedne praksis? Mine gamle pasienter ønsker det. Vi har opparbeidet et gjensidig tillitsforhold over 30-40 år som ingen ny lege kan erstatte nå. Jeg kjenner deres livshistorie, familie og miljø. Så lenge mitt arbeid er til nytte for mine pasienter og jeg selv har arbeidsglede og god helse, vil jeg søke om å få fortsette i min beskjedne praksis. Det er bare så underlig at vi også på dette området er et «annerledesland», særlig i en tid da levealderen er økende og eldre leger trengs mer enn noensinne.

\section{Per Steinar Steinsvoll}

Sel

\section{Leger i krig}

Ragnvald Bjørgaas Petersen antyder i Tidsskriftet nr. 3/2009 at Mads Gilbert og Erik Fosse blandet rollene som leger og politiske aktører i skildringene fra Gaza (1).

Leger som er vitne til at mennesker utsettes for lidelser, er moralsk forpliktet til å si ifra, jf. de etiske regler for leger kapittel I, $\S \S 1$ og 11 (2). Gilbert og Fosse risikerte ikke bare liv og helse for å hjelpe medmennesker i nød, de oppfylte også informasjonsplikten overfor verdenssamfunnet på en forbilledlig måte. Nettopp fordi de er leger og rapporterte om sine egne opplevelser viste de oss hva krig betyr av menneskelig lidelse - og det på en slik måte at ingen kunne være uberørt. Det er grunn til å tro at dette bidro til et ytre press mot partene og raskere avvikling av kamphandlingene. I tillegg kan vi håpe at det har vært en øyeåpner og et bidrag til generell avsky mot krig. Et politisk engasjement skal ikke være til hinder for å rapportere om menneskelig lidelse. Her var dette særlig uproblematisk fordi legene var åpne om hvem som hadde deres sympati - de hadde ingen skjult agenda.

Det er ikke uvanlig at regjeringer i land som vi ikke liker å sammenlikne oss med, forsøker å kneble leger fra å rapportere om urett og lidelse. Påstander om at de har en politisk agenda er en mild måte å forsøke å diskreditere dem på. World Medical Association (WMA) har flere ganger engasjert seg i slike saker, og da til støtte for leger som makthavere oppfatter som brysomme.

Gilbert og Fosse har vist at hele verden kan nås med enkelt kommunikasjonsutstyr. Det gir leger en ny mulighet til å rapportere fra konfliktområder. Det kan samtidig gjøre livet farligere fordi makthaverne kan oppleve dem som en trussel. Mer enn noen gang er det derfor viktig at medisinere generelt, Legeforeningen og WMA er tydelige i sin støtte til leger som våger å si ifra om urett.

\section{Trond Markestad}

Leder, Rådet for legeetikk

\footnotetext{
Litteratur

1. Petersen RB. Gaza. Tidsskr Nor Legeforen 2009: 129: 195.

. Etiske regler for leger. www.legeforeningen.no/id/ 485.1
} 